\title{
KEPARAHAN PENYAKIT ANTRAKNOSA PADA CABAI (Capsicum annuum L) DAN BERBAGAI JENIS GULMA
}

\author{
Kristina Hayu Herwidyarti, Suskandini Ratih \& Dad Resiworo Jekti Sembodo \\ Jurusan Agroteknologi, Fakultas Pertanian Universitas Lampung \\ J1. Soemantri Brodjonegoro No. 1 Bandar Lampung 35145 \\ E-mail:kristinaherwid@gmail.com
}

\begin{abstract}
ABSTRAK
Penelitian ini dilaksanakan di Laboratorium Penyakit Tumbuhan Fakultas Pertanian Universitas Lampung dan di lahan cabai di Kecamatan Kemiling, Kelurahan Langkapura Bandar Lampung pada bulan Juni hingga Agustus 2012. Penelitian ini disusun dalam rancangan acak kelompok (RAK) dengan 6 perlakuan dan 4 ulangan. Perlakuan terdiri dari (a) cabai, (b) Cleome rutidosperma, (c) Cyperus kyllingia, (d) Synedrella nodiflora, (e) Paspalum distichum, dan (f) Ageratum conyzoides yang diinokulasi dengan jamur Colletotrichum capsici pada saat tingginya berkisar antara 9-12 cm. Hasil penelitian menunjukkan bahwa; (1) Keparahan penyakit antraknosa berbeda-beda, pada cabai 0,3\% hingga 44,0\% \%, Cleome rutidosperma sebesar 7,5\% hingga 51,0\%, Cyperus kyllingia dan Paspalum distichum 0\%, Synedrella nodiflora 9,3\% hingga 47,0\%. dan Ageratum conyzoides $12,8 \%$ menjadi 9,1\%, (2) Masa inkubasi jamur Colletotrichum capsici berbeda-beda yaitu tersingkat pada gulma Cyperus kyllingia (0 hari), dan masa inkubasi terpanjang pada dan Paspalum conjugatum (27 hari). Pertumbuhan tinggi dan persentase jumlah daun tanaman cabai dan gulma yang diinokulasi dengan Colletotrichum capsici berbeda-beda dari minggu ke- 1 hingga minggu ke- 4. Pertumbuhan paling tinggi terjadi pada gulma Ageratum conyzoides sedangkan pertumbuhan terendah terjadi pada gulma Cleome rutidosperma. Persentase jumlah daun sakit paling besar adalah pada cabai dan Persentase jumlah daun paling kecil pada Cyperus kyllingia.
\end{abstract}

Kata Kunci: Ageratum conyzoides, Capsicum annuum, Cleome rutidosperma, Colletotrichum capsici, Cyperus kyllingia, Paspalum distichum, Synedrella nodiflora

\section{PENDAHULUAN}

Cabai merah (Capsicum annuum $\mathrm{L}$ ) merupakan salah satu komoditas sayuran penting. Kian hari kebutuhan cabai kian meningkat karena semakin bervariasinya jenis dan menu makanan yang memanfaatkan produk ini, juga karena semakin banyaknya jumlah konsumen yang membutuhkan (berkaitan dengan pertambahan jumlah penduduk) (Nawangsih, 1995).

Keberhasilan pertumbuhan tanaman cabai dipengaruhi oleh hama, penyakit tanaman, dan gulma. Menurut Raid dan Pennypacker (1987) dalam Bartz (2002) gulma yang tumbuh di sekitar pertanaman tomat dapat mempengaruhi pertumbuhan tanaman tomat sekaligus dapat menjadi inang Colletotrichum coccodes. Menurut Hartman, Manandhar, dan Sinclair (1986) dalam Johnson (2008) juga menyatakan bahwa jenis gulma yang ada dipertanaman famili Solanaceae (tanaman tomat) mempengaruhi tingginya keterjadian penyakit yang disebabkan oleh Colletotrichum $s p$.

Berdasarkan data Badan Pusat Statistik (BPS)(2009) Produksi cabai merah di Provinsi Lampung mencapai 203.680 kuintal, dengan sentra produksi utama di Lampung Barat (38.287 ha), Tanggamus (54.464 ha), Lampung Selatan (35.230 ha), dan Pesawaran (25.392 ha). Rendahnya produksi cabai disebabkan banyak faktor antara lain serangan organisme pengganggu tanaman (OPT) meliputi hama, penyakit dan gulma. Aktivitas gulma antara lain berkompetisi dalam memperoleh unsur hara dengan tanaman inang, menjadi inang bagi serangga vektor dan menjadi inang patogen penyakit tanaman (Ripangi, 2012). Penyakit yang sering terdapat pada pertanaman cabai adalah penyakit antraknosa (patek) yang disebabkan oleh patogen Colletotrichum spp. Penyakit ini bergejala mati pucuk yang berlanjut ke bagian tanaman sebelah bawah. Daun, ranting dan cabang menjadi kering berwarna coklat kehitam-hitaman. Pada batang cabai aservulus cendawan terlihat seperti tonjolan (Duriat, et al.2007). Patogenitas Colletotrichum sangat kuat sehingga dapat menurunkan produksi cabai.

Penelitian ini bertujuan mengetahui apakah gulma dapat terserang oleh jamur Colletotrichum Capsici dan menyebabkan seperti antraknosa yang pada umumnya menyerang tanaman cabai, Tujuan lain adalah untuk mengetahui ada atau tidak adanya perbedaan masa inkubasi penyakit antraknosa pada cabai dan gulma. 


\section{BAHAN DAN METODE}

Penelitian ini dilaksanakan di Laboratorium Penyakit Tumbuhan Fakultas Pertanian Universitas Lampung. Selain itu penelitian dilakukan pada tanaman cabai (in planta) yang ditanam di polybag dan diletakkan di lahan cabai di Kecamatan Kemiling, Kelurahan Langkapura Bandar Lampung pada bulan Juni hingga Agustus 2012.

Bahan- bahan yang digunakan dalam peneliitian ini meliputi: tanah, pupuk kandang, benih cabai hibrida F1 Belinda (rentan) terhadap penyakit antraknosa dan gulma Cleome rutidosperma, Cyperus kyllingia, Synedrella nodiflora, Paspalum distichum, dan Ageratum conyzoides.

Penelitian ini disusun dengan Rancangan Acak Kelompok (RAK). Pengelompokan berdasarkan pada fase pertumbuhan vegetatif gulma (mengingat bahwa gulma memiliki masa dormansi biji yang panjang sehingga dalam penelitian ini gulma yang digunakan tidak berupa bibit yang berasal dari biji tetapi menggunakan stek batang dari gulma yang tumbuh di alam). Keenam tumbuhan yang diinokulasi dengan penyebab antraknosa adalah : Cabai, gulma Cleome rutidosperma, Cyperus kyllingia, Synedrella nodiflora, Paspalum distichum, dan Ageratum conyzoides. Masing-masing perlakuan diulang empat kali sehingga diperoleh 24 satuan percobaan.

Penyiapan Media Tanam. Penyiapan media tanam dimulai dengan mengayak tanah, setelah itu dikeringanginkan selama tiga hari. Selanjutnya tanah dicampur dengan pupuk kandang, pupuk kompos dan dimasukkan ke dalam polibag (Perbandingan $7 \mathrm{~kg}$ tanah : $1 \mathrm{~kg}$ pupuk kandang : $1 \mathrm{~kg}$ kompos).

Penyemaian Cabai. Benih cabai direndam dalam air selama 24 jam. Benih cabai yang mengapung dibuang. Benih yang baik disemaikan langsung ke dalam polibag sebanyak 3 benih per polibag.

Penanaman Gulma. Stek batang gulma diambil dari gulma-gulma yang tumbuh secara alami di lahan pertanaman cabai. Kemudian dipindah tanamkan ke media polibag.

Penyiapan Isolat $\boldsymbol{C}$. capsici. Penyiapan isolat dilakukan di Laboratorium Penyakit Universitas Lampung. Isolat diperoleh dengan cara mengisolasi jamur $C$. capsici dari buah cabai yang bergejala antraknosa. Isolat ditumbuhkan pada media Agar
Glukosa Kentang (AGK) dalam cawan petri selama dua hingga tujuh hari.

Inokulasi Isolat Colletotrichum Pada Tanaman Cabai dan Gulma. C. capsici yang tumbuh dalam cawan petri umur tujuh hari setelah inkubasi dipanen dan disuspensikan dalam $100 \mathrm{ml}$ aquades. Selanjutnya isolat diinokulasikan pada tanaman cabai dan gulma dengan cara disemprotkan menggunakan handsprayer sebanyak $5 \mathrm{ml}$ dengan kerapatan $4.750 \times 10^{6} \mathrm{spora} / \mathrm{ml}$.

Penggamatan. Penggamatan dilakukan untuk mengetahui masa inkubasi dan keparahan penyakit.

1. Pengamatan masa inkubasi dilakukan sejak inokulasi hingga munculnya gejala.

2. Keparahan penyakit diamati setiap minggu dimulai dari sehari setelah inokulasi $C$. capsici sampai empat minggu. Keprahan penyakit dihitung dengan rumus (Zadoks dan Schein, 1979) sebagai berikut:

$$
I=\frac{\sum(n \times v)}{N \times Z} \times 100 \%
$$

Keterangan:

I = Intensitas tanaman terserang

$\mathrm{n}=$ Jumlah tanaman terserang

$\mathrm{v}=$ Nilai numerik tanaman yang diamati

$\mathrm{N}=$ Jumlah tanaman yang diamati

$\mathrm{V}=$ Nilai numerik kategori tertinggi

Nilai kategori serangan (skor) untuk penyakit antraknosa didasarkan pada skala kerusakan tanaman yang terserang penyakit (Herwidyarti, 2011 dimodifikasi). Nilai kategori serangan (skor) sebagai berikut:

$0=$ Tidak ada kerusakan

$1=$ Bercak seluas $1-20 \%$

$2=$ Bercak seluas $21-40 \%$

$3=$ Bercak seluas $41-60 \%$

$4=$ Bercak seluas $>60 \%$

Data yang diperoleh dianalisis ragam dan dilanjutkan dengan uji beda nyata terkecil (BNT) pada taraf nyata $5 \%$. Selain itu diamati pula tinggi tanaman dan persentase jumlah daun yang sakit.

\section{HASIL DAN PEMBAHASAN}

Tinggi Tanaman dan Persentase Jumlah Daun Sakit. Gulma yang digunakan sebagai tanaman inang alternatif antraknosa memiliki tinggi awal $9-12 \mathrm{~cm}$. Perbedaan tinggi antara gulma dan cabai terjadi setelah inokulasi patogen, dan berlanjut empat minggu setelah inokulasi jamur penyebab antraknosa. Tinggi tanaman 
cabai dan gulma dapat dilihat pada Tabel 1. Berdasarkan uji BNT, maka pertumbuhan tanaman cabai dan gulma yang diinokulasikan dengan jamur $C$. capsici berbedabeda sejak minggu ke-1 hingga minggu ke-4. Pertumbuhan paling cepat terjadi pada gulma $A$. conyzoides dan untuk pertumbuhan paling lambat (tumbuh paling rendah) adalah gulma $C$. rutidosprma. Sebagai pembanding diamati tinggi tanaman cabai dan gulma sehat (Tabel 2). Tanaman cabai dan gulma yang sehat lebih tinggi dibandingkan dengan tanaman cabai dan gulma sakit yang diinokulasi dengan $C$. capsici (Tabel 2). Dari pengamatan ini, terlihat bahwa cabai maupun gulma sehat lebih tinggi dibandingkan dengan cabai maupun gulma yang terserang penyebab penyakit antraknosa.

Gambar1 menyajikan tentang persentase jumlah daun sakit pada tanaman $C$. annuum menunjukkan kenaikan dari minggu pertama hingga minggu keempat. Persentase jumlah daun sakit gulma $C$. rutidosperma menunjukkan kenaikan dari minggu pertama hingga minggu kedua, namun pada saat memasuki minggu ketiga mengalami penurunan dan pada saat minggu keempat mengalami kenaikan kembali.

Persentase jumlah daun sakit gulma $C$. kyllingia sejak minggu pertama hingga minggu keempat tetap. Persentase jumlah daun sakit gulma $S$. nodiflora mengalami penurunan pada minggu kedua hingga minggu ketiga dan pada saat minggu keempat mengalami kenaikan kembali. Sedangkan gulma $P$. distichum mengalami kenaikan pada minggu keempat. Gulma A. conyzoides mengalami kenaikan saat minggu ke dua hingga minggu keempat. Terjadinya pengurangan persentase jumlah daun sakit karena $C$. capsici menyebabkan ranting-ranting muda mati mengering sehingga daun yang tumbuh pada ranting tersebut mengalami kerontokan (Semangun, 2000).

Keparahan Penyakit pada Cabai dan Beberapa Jenis Gulma. Tabel3 menunjukkan bahwa gulma yang digunakan sebagai tanaman inang alternatif antraknosa

Tabel 1. Tinggi Tanaman Cabai dan Gulma yang menunjukkan gejala sakit setelah perlakuan

\begin{tabular}{lcccc}
\hline \multirow{2}{*}{ Perlakuan } & \multicolumn{4}{c}{ Tinggi Tanaman $(\mathrm{cm})$} \\
\cline { 2 - 5 } & Minggu ke- 1 & Minggu ke- 2 & Minggu ke- 3 & Minggu ke- 4 \\
\hline Capsicum annuum & $16,8 \mathrm{ab}$ & $23,3 \mathrm{abc}$ & $29,5 \mathrm{abc}$ & 32,0 abcde \\
Cleome rutidosperma & $16,6 \mathrm{a}$ & $20,0 \mathrm{a}$ & $24,0 \mathrm{a}$ & $25,9 \mathrm{a}$ \\
Cyperus kyllingia & $17,6 \mathrm{abc}$ & $22,1 \mathrm{ab}$ & $28,5 \mathrm{ab}$ & $30,3 \mathrm{ab}$ \\
Synedrella nodiflora & $20,1 \mathrm{abcd}$ & $25,6 \mathrm{abcd}$ & $30,8 \mathrm{abcde}$ & $31,9 \mathrm{abcd}$ \\
Paspalum distichum & $21,3 \mathrm{abcde}$ & $25,8 \mathrm{abcde}$ & $29,8 \mathrm{abcd}$ & $31,8 \mathrm{abc}$ \\
Ageratum conyzoides & $37,0 \mathrm{f}$ & $40,0 \mathrm{f}$ & $42,8 \mathrm{f}$ & $44,1 \mathrm{f}$ \\
\hline BNT 0,05 & 5,10 & 6,14 & 7,23 & 6,28 \\
\hline
\end{tabular}

Keterangan: huruf yang sama dibelakang angka dalam satu kolom menunjukkan tidak berbeda nyata pada uji BNT $\alpha_{0,05}$.

Tabel 2. Tinggi Tanaman Cabai dan Beberapa Jenis Gulma yang tetap sehat.

\begin{tabular}{lllcc}
\hline \multirow{2}{*}{ Perlakuan } & \multicolumn{4}{c}{ Tinggi Tanaman $(\mathrm{cm})$} \\
\cline { 2 - 5 } & Minggu ke- 1 & Minggu ke- 2 & Minggu ke- 3 & Minggu ke- 4 \\
\hline Capsicum annuum & $18,00 \mathrm{a}$ & $30,00 \mathrm{abc}$ & $53,00 \mathrm{~cd}$ & $60,00 \mathrm{~d}$ \\
Cleome rutidosperma & $21,00 \mathrm{ab}$ & $22,00 \mathrm{a}$ & $26,00 \mathrm{a}$ & $31,00 \mathrm{a}$ \\
Cyperus kyllingia & $22,00 \mathrm{abc}$ & $24,00 \mathrm{ab}$ & $30,00 \mathrm{ab}$ & $33,00 \mathrm{ab}$ \\
Synedrella nodiflora & $23,00 \mathrm{abcd}$ & $32,00 \mathrm{abcd}$ & $43,00 \mathrm{bc}$ & $46,00 \mathrm{c}$ \\
Paspalum distichum & $27,00 \mathrm{abcde}$ & $47,00 \mathrm{e}$ & $74,00 \mathrm{e}$ & $78,00 \mathrm{e}$ \\
Ageratum conyzoides & $41,00 \mathrm{f}$ & $58,00 \mathrm{e}$ & $76,00 \mathrm{e}$ & $79,00 \mathrm{e}$ \\
\hline BNT 0,05 & \multicolumn{4}{c}{12,44} \\
\hline
\end{tabular}

Keterangan: huruf yang sama dibelakang angka dalam satu kolom menunjukkan tidak berbeda nyata pada uji BNT $\alpha_{0,05}$. 
C. capsici pada cabai dan beberapa gulma menyebabkan perbedaan keparahan penyakit antraknosa.

Pada minggu ke-1, keparahan penyakit antraknosa tertinggi terjadi pada gulma A. conyzoides (wedusan) dengan keparahan penyakit 12,8\%, kemudian S. nodiflora 9,3\% dan C. rutidosperma 7,5\%. Hal ini terjadi hingga minggu ke-2. Pada minggu ke-3 keparahan penyakit pada cabai meningkat, yang semula pada minggu ke-1 dan ke-2 hanya sebesar 0,3\% - 5,1 $\%$ meningkat menjadi $23,3 \%$. sama parahnya dengan keparahan penyakit pada $C$. rutidosperma dan S.nodiflora. A. conyzoides menunjukkan penurunan keparahan penyakit antraknosa pada minggu ke-3 ini yaitu $8,4 \%$. Pada minggu ke-4 keparahan tanaman cabai, $C$. rutidosperma dan $S$. nodiflora tetap tinggi, yaitu $44,0 \%, 51,0 \%$ dan 47,0\%. Sedangkan keparahan penyakit antraknosa pada $A$. conyzoides pada minggu ke-4 mengalami kenaikan yaitu $9,1 \%$. Gulma $P$. distichum (Rumput pahit) dan gulma C. kyllingia (teki) memiliki tingkat serangan yang tetap sejak minggu ke-1 hingga minggu ke- 4 yaitu sebesar $0 \%$.

Masa Inkubasi Jamur Colletotrichum capsici pada Cabai dan Gulma. Selain terdapat perbedaan keparahan penyakit antraknosa pada cabai dan gulma terlihat pula adanya perbedaan masa inkubasi penyakit antraknosa dari sejak inokulasi jamur $C$. capsici hingga munculnya gejala bercak pada daun cabai dan gulma. Masa inkubasi penyakit antraknosa pada cabai dan gulma C. rutidosperma yaitu 12 hari. Sedangkan masa inkubasi pada $C$. kyllingia (teki) yaitu 0 hari dan masa inkubasi antraknosa pada $S$. nodiflora yaitu 8 hari. Gulma P. distichum (rumput pahit) memiliki masa inkubasi 27 hari, itu pun hanya terjadi pada dua ulangan. Masa inkubasi pada gulma $A$. conyzoides yaitu 7 hari.

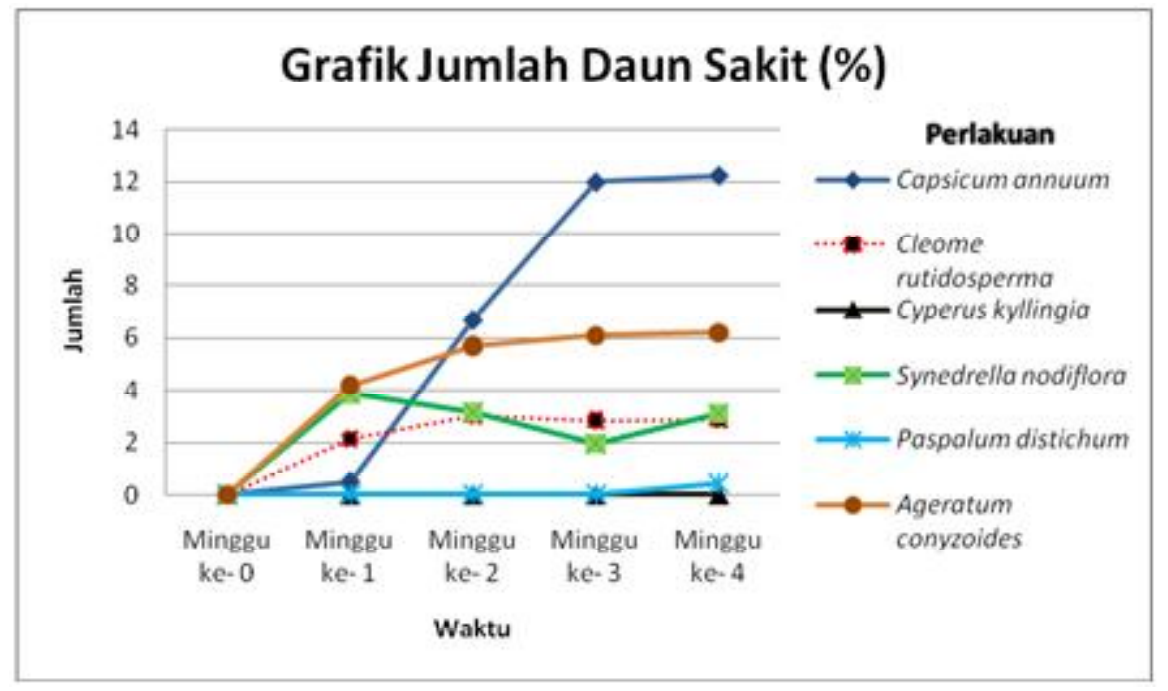

Gambar 1. Grafik persentase jumlah daun sakit

Tabel 3. Keparahan penyakit pada cabai dan beberapa jenis gulma

\begin{tabular}{lcccc}
\hline \multicolumn{1}{c}{ Perlakuan } & Minggu ke- 1 & Minggu ke- 2 & Minggu ke- 3 & Minggu ke- 4 \\
\hline Capsicum annuum & $0,3(1,2 \mathrm{ab})$ & $5,1(1,7 \mathrm{~b})$ & $23,3(2,3 \mathrm{c})$ & $44,0(2,5 \mathrm{~d})$ \\
Cleome rutidosperma & $7,5(1,8 \mathrm{c})$ & $20,5(2,2 \mathrm{c})$ & $32,3(2,5 \mathrm{~d})$ & $51,0(2,7 \mathrm{~d})$ \\
Cyperus kyllingia & $0,0(1,1 \mathrm{a})$ & $0,0(1,1 \mathrm{a})$ & $0,0(1,1 \mathrm{a})$ & $0,0(1,1 \mathrm{a})$ \\
Synedrella nodiflora & $9,3(1,9 \mathrm{c})$ & $20,0(2,2 \mathrm{c})$ & $30,8(2,5 \mathrm{~d})$ & $47,0(2,7 \mathrm{~d})$ \\
Paspalum distichum & $0,0(1,1 \mathrm{a})$ & $0,0(1,1 \mathrm{a})$ & $0,0(1,1 \mathrm{a})$ & $0,0(1,2 \mathrm{ab})$ \\
Ageratum conyzoides & $12,8(2,0 \mathrm{c})$ & $43,3(2,6 \mathrm{~d})$ & $8,4(1,8 \mathrm{~b})$ & $9,1(2,1 \mathrm{c})$ \\
\hline BNT 0,05 & 0,22 & 0,25 & 0,08 & 0,21 \\
\hline
\end{tabular}

Keterangan: angka dalam kurung merupakan hasil transformasi akar $x+0,5$. Huruf yang sama dibelakang angka dalam satu kolom menunjukkan tidak berbeda nyata pada uji BNT $\alpha_{0,05}$. 
Tabel 4. Masa inkubasi jamur Colletotrichum capsici pada cabai dan gulma

\begin{tabular}{lc}
\hline \multicolumn{1}{c}{ Perlakuan } & Hari ke \\
\hline Capsicum annuum & $12 \mathrm{c}$ \\
Cleome rutidosperma & $12 \mathrm{c}$ \\
Cyperus kyllingia & $0 \mathrm{a}$ \\
Synedrella nodiflora & $8 \mathrm{c}$ \\
Paspalum distichum & $27 \mathrm{e}$ \\
Ageratum conyzoides & $7 \mathrm{~b}$ \\
\hline BNT 0,05 & 1,27 \\
\hline
\end{tabular}

Keterangan: huruf yang sama dibelakang angka menunjukkan tidak berbeda nyata pada uji BNT $\alpha_{0,05}$.

\section{KESIMPULAN}

Berdasar hasil penelitian dapat disimpulkan bahwa keparahan penyakit antraknosa berbeda-beda, berurutan pada cabai $0,3 \%$ hingga $44,0 \%$, pada gulma $C$. rutidosperma sebesar 7,5\% hingga 51,0\%, gulma C. kyllingia $0 \%$, untuk gulma $S$. nodiflora $9,3 \%$ hingga 47,0\%, gulma $P$. distichum $0 \%$, dan gulma $A$. conyzoides $12,8 \%$ menjadi $9,1 \%$ (menurun). Masa inkubasi jamur $C$. capsici berbeda-beda pada cabai dan gulma. Masa inkubasi terpendek terjadi pada gulma $C$. kyllingia (teki) yaitu 0 hari (tidak memiliki masa inkubasi), sedangkan masa inkubasi terpanjang terjadi pada dan $P$. conjugatum (rumput pahit) yaitu 27 hari (yang hanya terjadi pada dua ulangan). Pertumbuhan tinggi dan persentase jumlah daun tanaman cabai dan gulma yang diinokulasi dengan $C$. capsici berbeda-beda dari minggu ke- 1 hingga minggu ke- 4 . Pertumbuhan paling tinggi terjadi pada gulma $A$. conyzoides sedangkan pertumbuhan terendah terjadi pada gulma $C$. rutidosperma. Persentase jumlah daun sakit paling besar adalah pada cabai, dan Persentase jumlah daun sakit paling kecil pada C. kyllingia.

\section{DAFTAR PUSTAKA}

Bartz, J.A., dan J.K.Brecht. 2002. Postharvest Physiology and Pathology of Vegetables. CRC Press. USA. $744 \mathrm{Hlm}$.
Duriat, A.S., N.Gunaeni., dan A.W.Wulandari. 2007. Penyakit Penting Pada Tanaman Cabai dan Pengendaliannya. Balai Penelitian Tanaman Sayuran. Bandung. $55 \mathrm{hlm}$.

Herwidyarti, K.H. 2011. Pengamatan Keparahan Penyakit Bercak Daun Ungu (Alternaria porri (Ell.)Cif) Tanaman Bawang Daun Di Balai Penelitian Tanaman Sayuran Lembang Bandung. Laporan Praktik Umum. Fakultas Pertanian Universitas Lampung. Bandar Lampung. $44 \mathrm{hlm}$.

Johnson, L.A., P.J.White, dan R.Galloway. 2008. Soybeans Chemistry, Production, Processing and Utilization. AOCS Press. USA. $842 \mathrm{Hlm}$.

Nawangsih, A.A., H.P.Imdad., dan A.Wahyudi. 1995. Cabai Hot Beauty. Penebar Swadaya. Jakarta. $114 \mathrm{hlm}$.

Ripangi, A. 2012. Budidaya Cabai. PT. Buku Kita. Jakarta. $97 \mathrm{hlm}$.

Semangun, H. 2000. Penyakit-Penyakit Tanaman Hortikultura Di Indonesia. Gadjah Mada University Press. Yogyakarta. $850 \mathrm{hlm}$.

Zadoks, J.C and R.D. Schein. 1979. Epidemiology and Plant Disease Management. Oxford University Press. New York. 427 pp. 